\title{
Desmodus rotundus (Mammalia: Chiroptera) on the southern coast of Rio de Janeiro state, Brazil
}

\author{
Costa, LM.* and Esbérard, CEL. \\ Instituto de Biologia, Universidade Federal Rural do Rio de Janeiro - UFRRJ, \\ Km 47 da antiga estrada Rio - São Paulo, CP 74507, CEP 23890-000, Seropédica, RJ, Brazil \\ *e-mail: lucianamcosta@yahoo.com.br
}

Received July 15, 2010 - Accepted September 15, 2010 - Distributed August 31, 2011

(With 2 figures)

\begin{abstract}
Since the 1990s, attacks by hematophagous bats on humans and domestic animals have been reported both on the continent and on the islands on the southern coast of Rio de Janeiro state. The density of vampire bats was investigated based on percentage of captures during control of Desmodus rotundus samplings and during bat diversity research. In the present work, 203 individuals of D. rotundus were captured from 1993 to 2009, which corresponds to $11.88 \%$ of all bat captures carried out for species control in local villages and $1.58 \%$ of all captures in faunistic inventories. The density of $D$. rotundus is high even on the recently occupied islands where domestic animals have been introduced. It is probable that this species dispersed from the continent to the islands due to the introduction of domestic animals.
\end{abstract}

Keywords: density, movements, public health, vampire bats.

\section{Desmodus rotundus (Mammalia: Chiroptera), na costa sul do estado do Rio de Janeiro, Brasil}

\section{Resumo}

Desde 1990 ataques de morcegos hematófagos em humanos e animais domésticos têm sido reportados tanto no continente como nas ilhas da costa sul do estado do Rio de Janeiro. A densidade de morcegos vampiros foi investigada baseada na percentagem de capturas durante amostragens para o controle de Desmodus rotundus e durante amostragens para pesquisas da diversidade. No presente trabalho 203 indivíduos de D. rotundus foram capturados entre 1993 e 2009 , que correspondem a 11,88\% de todas as capturas de morcegos para o controle da espécie em vilarejos locais e 1,58\% de todas as capturas em inventários faunísticos. A densidade de $D$. rotundus é alta mesmo em ilhas recentemente ocupadas onde animais domésticos foram introduzidos. É provável que esta espécie disperse a partir do continente para as ilhas devido à introdução dos animais domésticos.

Palavras-chave: densidade, movimentos, saúde pública, morcegos vampiros.

\section{Introduction}

Desmodus rotundus (Geoffroy, 1810) is an obligatory hematophagous bat that feeds on birds and mammals, and uses a wide range of prey (e.g. Gardner, 1977; Greenhall and Schmidt, 1988). This species is responsible for heavy losses in livestock farming activities (Acha and Malaga-Alba, 1988; Delpietro et al., 1992; Brass, 1994; Nowak, 1995). Its population has gradually increased in the neotropical region (Jones, 1976), since a density increase was observed next to areas of livestock farming (Delpietro et al., 1992) and it can even be found in large Brazilian urban centres (Bredt and Uieda, 1996; Esbérard et al., 1998, 2001; Torres et al., 2005; Ferraz et al., 2007). Desmodus rotundus is one of the most important vectors of rabies, and many deaths are associated with bat bites (Brass, 1994). Rabies is a deadly infection caused by a virus that attacks the nervous system. This disease has been known since $300 \mathrm{BC}$ and has a worldwide distribution, where it is responsible for the deaths of ca. 30,000 people per year. Annually, about four million people need preventive treatment against rabies (Brass, 1994). Even so, little importance is given to rabies and its vectors, and in many areas of Latin America, the authorities take no effective action to control hematophagous bats (Linhart, 1975).

Desmodus rotundus inhabits all kinds of environments, and high densities have been reported in cattle-raising areas in Argentina, where it can reach twice the density as found in more natural areas (Delprieto et al., 1992). In Costa Rica a density of 1.0 bat for every 13 ha was reported by Turner (1975). The frequency of capture of this bat in areas far from farms or cave areas was low or 
medium, usually not as high as $2 \%$ of all bat captures of the inventory in the Atlantic Forest (e.g. Peracchi and Albuquerque, 1993; Teixeira and Peracchi, 1996; Pedro and Taddei, 1997; Portfors et al., 2000; Faria et al., 2006).

Therefore, the aims of the present study were to report the relative abundance of $D$. rotundus captured during samplings on islands and on the continent, and to compare between surveys to control this species, as well as to compare biodiversity inventories. We also discuss whether the recent human occupation of the islands in Sepetiba creek and Ilha Grande may have interfered in bat dispersion and abundance.

\section{Methods}

The study region comprises an area of $4,100 \mathrm{~km}^{2}$, which includes the municipalities of Seropédica, Itaguaí, Mangaratiba, Angra dos Reis, Rio Claro and Paraty, and some islands on Sepetiba and Ilha Grande creeks, southeastern Rio de Janeiro state, Brazil (Figure 1). The region's vegetation is classified as Dense Tropical Wet Forest, which includes coastal restingas and mangroves (Ururahy et al., 1983). This area is currently the largest continuous forest in Rio de Janeiro state, but it has been affected by the increase in tourism and human occupation (Fidalgo et al., 2007). The coast of Rio de Janeiro state has over 400 islands, and many of them are populated. Among them stands out Ilha Grande, the largest island in Rio de Janeiro state, besides others with remnants of native vegetation (Alho et al., 2002).

The occupation of those islands was established in the XVI century, when the slave trade was their main economic activity. Next, there were the coffee and sugarcane cycles, which resulted in huge deforestation in the region, including some islands, such as Ilha Grande and Ilha da Gipóia (Maciel et al., 1984; Araujo and Oliveira, 1988; Alho et al., 2002). Human occupation has been increasing with the development of tourism and hotel industries and over the last 20 years, many islands have become more densely occupied and received domestic animals.

From 1993 to 2009, 351 sampling nights were carried out to capture $D$. rotundus or to make inventories of the bat fauna in different localities of the southern coast of Rio de Janeiro state (Esbérard et al., 2006; Esbérard and Bergallo, 2008). Twenty-one localities were surveyed (Figure 1), mostly in the villages where attacks by $D$. rotundus on humans and domestic animals were reported. During surveys for vampire bat control, each site was netted until attacks on domestic animals were no longer observed or reported (one to six nights). We used four or more nets set all night long next to the attacked animal and also over streamlets, forest edges or existent trails in the forested area nearby

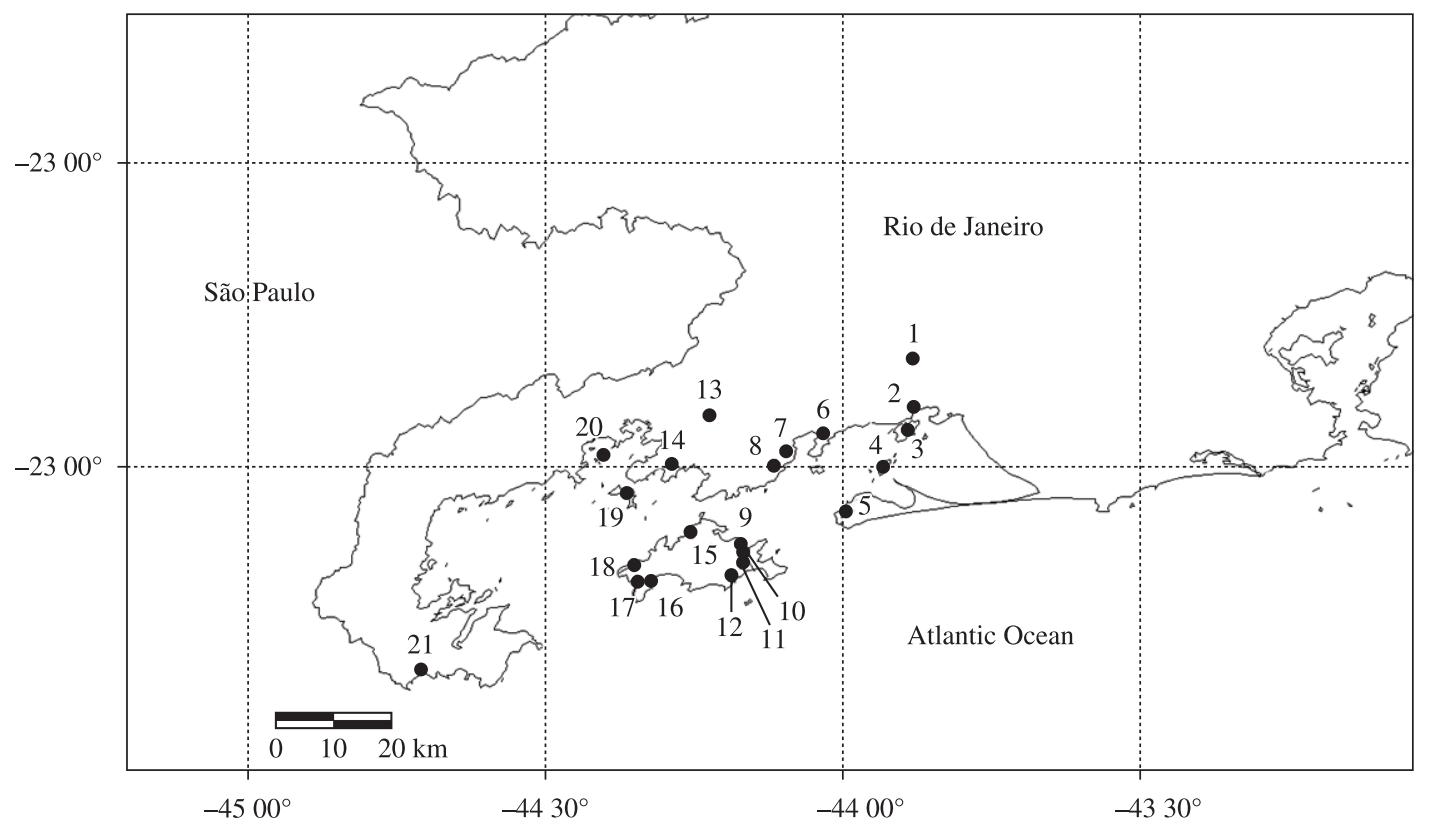

Figure 1. Location of the surveyed sites on the southern coast of Rio de Janeiro state from 1993 to 2009. 1) Campus of the Universidade Federal Rural do Rio de Janeiro (Seropédica); 2) Parada Costa Verde (Itaguaí); 3) Ilha de Jaguanum (Mangaratiba); 4) Ilha de Itacuruçá (Mangaratiba); 5) Ilha da Marambaia (Mangaratiba); 6) Terras do Sahy Farm (Mangaratiba); 7) Portobello Farm (Mangaratiba); 8) Rio das Pedras Ecological Reserve (Mangaratiba); 9) Praia Preta, Ilha Grande (Angra dos Reis); 10) Cachadaço Trail, Ilha Grande (Angra dos Reis); 11) Abraão Village, Ilha Grande (Angra dos Reis); 12) Dois Rios Village, Ilha Grande (Angra dos Reis); 13) Lídice (Angra dos Reis); 14) Angra dos Reis (centre); 15) Jararaca Trail, Ilha Grande (Angra dos Reis); 16) Praia do Bananal, Ilha Grande (Angra dos Reis); 17) Praia do Aventureiro, Ilha Grande (Angra dos Reis); 18) Praia de Provetá, Ilha Grande (Angra dos Reis); 19) Ilha da Gipóia (Angra dos Reis); 20) Ilha das Palmeiras (Angra dos Reis); 21) Praia do Sono (Paraty). 
(maximum of $20 \mathrm{~m}$ distance from prey or feeding roost of D. rotundus). During sampling for the biodiversity inventory, the nets remained opened all night long and were set mainly on large trails in forested areas, on forest fragment edges, and also in banana plantations, backyards and at longer distances from any attacked animal (over $50 \mathrm{~m}$ ). On some nights (two to four), some nets were set next to potential prey, such as domestic animals in order to capture and indentify hematophagous species. Sampling for the biodiversity inventory was carried out from 1 to 189 nights in each location.

An active search to locate roosts of $D$. rotundus was accomplished in all localities, including hollow trees, caves and abandoned houses, with or without the inhabitants help. The attacks of $D$. rotundus were confirmed by the presence of wounds or bleeding in living or dead prey, as well as from information from inhabitants of the islands.

Desmodus rotundus specimens captured during this procedure were killed for other research purposes related to biometric and genetic studies. Euthanasia was performed using ether. Samplings were previously authorised by the Instituto Brasileiro do Meio Ambiente e Recursos Naturais Renováveis and all carcasses were deposited in the reference collection of the Laboratório de Diversidade de Morcegos in the Universidade Federal Rural do Rio de Janeiro (IBAMA, process 1755/89-SUPESRJ).

\section{Results}

Two hundred and three specimens of $D$. rotundus were captured: 68 on the continent and 135 on the islands (Table 1). Desmodus rotundus corresponded to $13.97 \pm 9.20 \%$ (mean \pm sd) out of 573 bat captures during samplings for vampire control and $1.54 \pm 0.72 \%$ out of 9,887 bat captures during faunal inventories. Even on the surveyed islands $(\mathrm{N}=6)$ this species density may be considered high: 135 individuals ( $1.63 \%$ out of 8,258 captures), but inferior to values observed on the continent $(3.09 \%$ out of 2,202 captures). Despite the sampling effort accomplished, we did not find roosts occupied by this bat species in any of the localities surveyed. The other two species of hematophagus bats were rare, with Diphylla ecaudata Spix, 1823 represented by two individuals in one locality and Diaemus youngi (Jentink, 1893) with three individuals in three localities.

The accumulation curve of $D$. rotundus suggest a continuous increasing of the density $\left(y=0.45 \mathrm{x}^{2}-\right.$ $\left.1771.6 \mathrm{x}+0.2^{-6}, \mathrm{r}=0.97, \mathrm{~F}=286.241, \mathrm{p}<0.001\right)$ in the localities surveyed (Figure 2). Sixteen species were attacked or suspected to be attacked by D. rotundus: nine mammals, comprising humans, and seven birds (Table 2). The species most frequently attacked was the chicken [Gallus gallus (Linnaeus, 1758)] in 12 out of 21 localities surveyed.

\section{Discussion}

Desmodus rotundus may be considered either a common or less common species at different localities in the southern coast of Rio de Janeiro. During samplings for the species inventory, this bat species represented over $1.5 \%$ of all captures, whereas a high capture rate was observed on the nights intended solely for vampire control (11.88\%). The majority of the bat species obtained during inventories show intermediate frequencies and can be considered common or

Table 1. Total captures of Desmodus rotundus and other species of hematophagus bats in southern Rio de Janeiro state from 1993 to 2009.

\begin{tabular}{|c|c|c|c|c|c|c|}
\hline $\mathbf{n}^{\mathbf{0}}$ & Localities & $\begin{array}{l}\text { Type of } \\
\text { survey }\end{array}$ & Nights & Captures & D. rotundus & $\begin{array}{l}n^{\circ} \text { other } \\
\text { species }\end{array}$ \\
\hline \multicolumn{7}{|c|}{ Mainland localities } \\
\hline 1 & UFRRJ Campus & Inventory & 4 & 132 & $1(0.76 \%)$ & - \\
\hline 2 & Parada Costa Verde & Inventory & 1 & 75 & $1(1.33 \%)$ & - \\
\hline 6 & Terras do Sahy Farm & Inventory & 2 & 154 & $2(1.30 \%)$ & 1D. youngi \\
\hline 7 & Portobello Farm & Control & 11 & 348 & $21(6.03 \%)$ & - \\
\hline 8 & Rio das Pedras Ecological Reserve & Inventory & 42 & 1,289 & $34(2.64 \%)$ & - \\
\hline 13 & Lidice & Control & 2 & 8 & $2(25.00 \%)$ & - \\
\hline 14 & Angra dos Reis (centre) & Control & 1 & 6 & $1(16.67 \%)$ & - \\
\hline 21 & Praia do Sono & Control & 2 & 190 & $6(3.16 \%)$ & - \\
\hline \multicolumn{7}{|c|}{ Islands } \\
\hline 3 & Ilha de Jaguanum & Inventory & 6 & 186 & $4(2.15 \%)$ & - \\
\hline 4 & Ilha de Itacuruçá & Inventory & 23 & 977 & $3(0.31 \%)$ & 2 D. ecaudata** \\
\hline 5 & Ilha da Marambaia & Inventory & 33 & 1,991 & $39(1.96 \%)$ & 1 D. youngi \\
\hline $9 *$ & Ilha Grande & Inventory & 189 & 3,042 & $45(1.48 \%)$ & - \\
\hline 19 & Ilha da Gipóia & Inventory & 33 & 2,041 & $40(1.95 \%)$ & 1 D. youngi \\
\hline \multirow[t]{2}{*}{20} & Ilha das Palmeiras & Control & 2 & 21 & $4(19.04 \%)$ & - \\
\hline & Total & & 351 & 10,460 & $203(1.94 \%)$ & \\
\hline
\end{tabular}

$\mathrm{n}^{\circ}$ - Number on map. *Includes the localities 9-12 and 15-19.**Netted near the chicken house. 


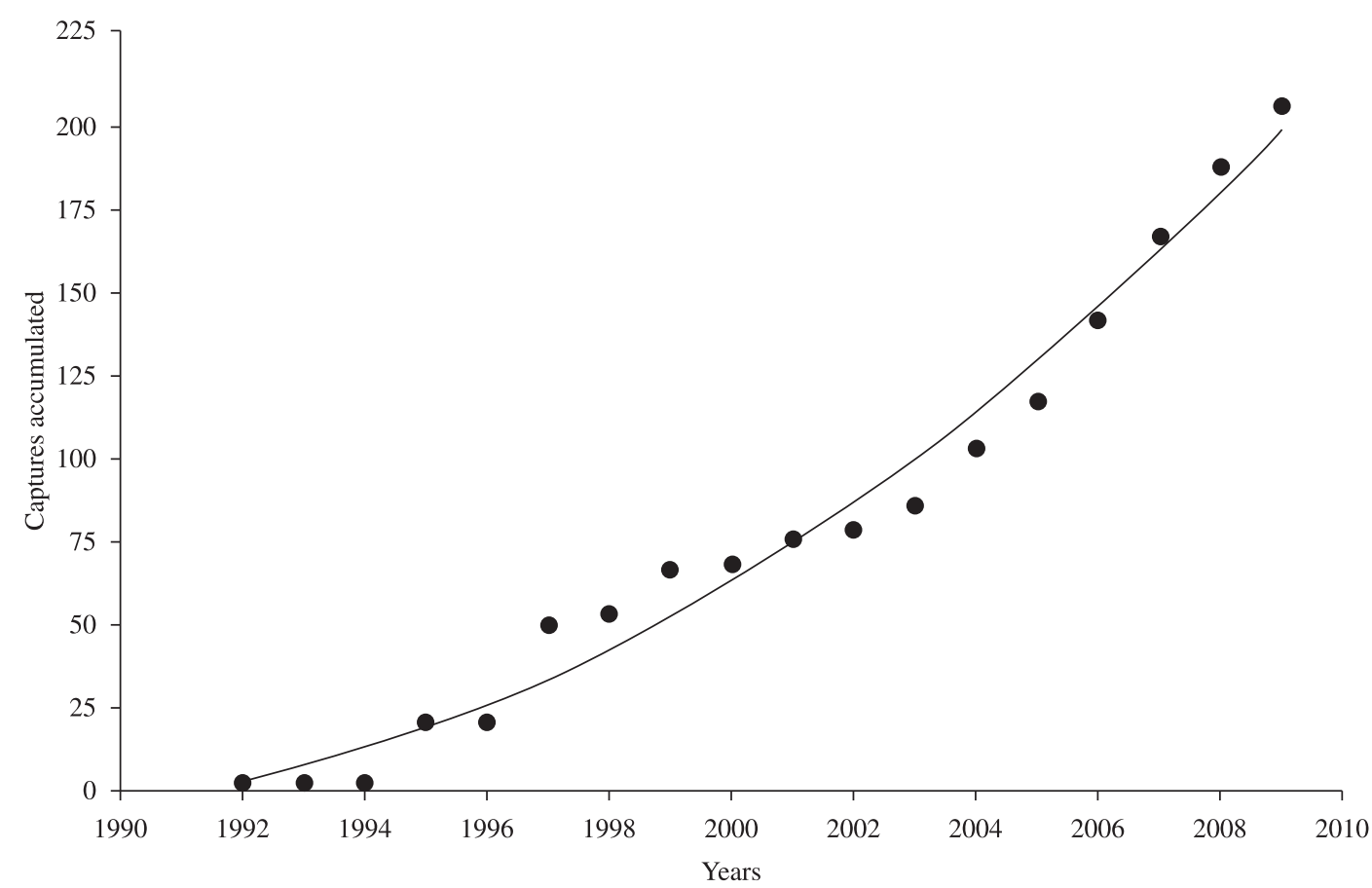

Figure 2. Accumulation curve of Desmodus rotundus by year on the southern coast of Rio de Janeiro state from 1993 to 2009.

Table 2. Confirmed or reported prey of Desmodus rotundus in the surveyed localities of southern coast of Rio de Janeiro state from 1993 to 2009. The numbers refer to the legend of Figure 1.

\begin{tabular}{llc}
\hline \multicolumn{1}{c}{ Vulgar name } & \multicolumn{1}{c}{ Scientific name } & Localities \\
\hline Horse & Equus cabalus (Linnaeus, 1758) & $1,2,7,18$ \\
Dog & Canis familiaris (Linnaeus, 1758) & $3,4,15,16,19,20$ \\
Fowl & Galus gallus (Linnaeus, 1758) & $3^{*}, 4,8-11,14-17,19,21$ \\
Donkey & Equus asinus (Linnaeus,1758) & $6,7,19,21$ \\
Eland & Taurotragus oryx (Wagner 1885) & 7 \\
Sambar Deer & Cervus unicolors (Kerr,1792) & 7 \\
Ox & Bos taurus (Linnaeus, 1758) & 7,12 \\
Swine & Sus scrofa (Linnaeus, 1758) & 8,14 \\
Man & Homo sapiens (Linnaeus, 1758) & $14,16,19,21$ \\
Goat & Capra hircus (Linnaeus, 1758) & 19 \\
Goose & Anser cygnoides (Linnaeus,1758) & 19 \\
Duck & Cairina moschata (Linnaeus, 1758) & 19 \\
Turkey & Meleagris gallopavo (Linnaeus, 1758) & 19 \\
Peacock & Pavo cristatus (Linnaeus, 1758) & $19 * *$ \\
Helmeted Guinea fowl & Numida meleagris (Linnaeus, 1758) & 19,20 \\
Unknown Species & & 13 \\
\hline
\end{tabular}

* Possible including Diphylla ecaudata attacks; ** Possible including Diaemus youngi attacks.

less common (Esbérard et al., 2006; Esbérard and Bergallo, 2008; Esbérard, 2009). In natural areas, the density of this bat is usually medium or low, rarely exceeding more than $2 \%$ of the total of captures (Peracchi and Albuquerque, 1993; Teixeira and Peracchi, 1996; Pedro and Taddei, 1997; Portfors et al., 2000; Faria et al., 2006). Higher densities were usually associated with farming (Delprieto et al., 1992) or proximity to roosts (Taddei and Pedro, 1996).
Even in forest remnants inside urban areas, densities moderate to high (3-4\%) of these hematophagus bats can be achieved (Esbérard, 2003). The other Desmodontinae species showed lower frequency, both with $0.05 \%$ of the total captures and $2.40 \%$ of the total of hematophagus bats.

In the present study, D. rotundus was observed feeding on a wide range of prey, which was expected because this species is far more generalist than the other two vampire 
species (e.g. Gardner, 1977; Greenhall and Schmidt, 1988). Attacks on humans were reported in four localities and confirmed in one locality through the capture of two individuals when entering a residence of a previously attacked person. Attacks on humans are considered rare events (Bredt et al., 1996), and they are more frequent in the northern and northeastern regions of Brazil (e.g. Almansa and Garcia, 1980; Carranza and Del-Campo, 1980; Schneider et al., 2001; Gonçalves et al., 2002; Mayen, 2003). McCarthy (1989) stated that D. rotundus attacked humans after a reduction of the local swine population, and then the attack rate on humans decreased when the bats targeted new species as prey. But in some localities humans can be a most frequent prey, as reported by Baer (1991) findings of $17.5 \%$ of 70 vampire bats feeding on people in Colima, Mexico.

Apparently the high density of prey may stimulate the dispersion of D. rotundus to islands where domestic animals were introduced, since no attack or dead animals such as dogs was reported before the introduction of birds on Ilha da Gipóia. The apparent recent dispersion of the species to the studied islands, where attacks have frequently been reported, is a more likely hypothesis than the existence of specimens before human occupation. Hematophagous bats forage in an area $5-8 \mathrm{~km}$ away from their day roost, but there are reports of their commuting distances of up to 20 km (Málaga-Alba, 1954; Crespo et al., 1961; Greenhall and Schmidt, 1988; Medina et al., 2007). In vampire bats studied with radio-telemetry, the average distance from the day roost to foraging site is $1.89 \mathrm{~km}$ (Wimsatt, 1969), which is similar to the longest distance between the studied islands and the continent (maximum of $2 \mathrm{~km}$ ). It is not impossible that on the islands nearer to the mainland the animals use a mainland locality for roosting and forage periodically or on a daily-basis to the islands. Such a hypothesis seems to be less likely, since the high daily energy loss would result in a low reproductive investment (McNab, 1973). Besides, Turner (1975) analysed the average commuting distance and noticed that $D$. rotundus changes roosts in order to decrease the distance from the cattle previously attacked. Since $D$. rotundus can adapt to artificial and natural roosts, it may find on the islands hollow trees, caves, basements, abandoned houses and other suitable structures (Gomes and Uieda, 2004), and the availability of these roosts may not be a limiting factor.

The existence of such a high population density of this bat previous to increased human occupation of those islands also seems unlikely, because it would require a large source of prey to maintain a large long-term population of this bat. In the studied region, 43 species of non-flying mammals are currently found, but medium or big sized native species are rare or even absent (Pereira et al., 2001). Taking into account that each hematophagous bat ingests ca. $20 \mathrm{~g}$ of blood/night (McNab, 1973), we can imagine that to maintain all adult specimens of $D$. rotundus captured on Ilha Grande, at least $0.9 \mathrm{~kg}$ of blood/night and $329 \mathrm{~kg}$ of blood per year would be necessary. If we estimate the amount of blood as $10 \%$ of body mass, it would require on this island, for instance, at least between 20 to 30 adult bovines. If this amount of cattle is not at hand, such a high density of vampire bats would have resulted in a great number of humans attacked every night. However, the number of attacks on humans is apparently scanty and restricted to certain localities, and the number of bovines and equines on this island has always been kept to the minimum; the maximum reported were three adult specimens, which were excluded from the island in 1998.

On at least one of the islands, Ilha da Gipóia, specimens of the helmeted guinea fowl Numida meleagris (Linnaeus, 1758) were introduced by inhabitants as a way to control snakes [Jararacas, Bothrops jararaca (Wied, 1924)]. Those birds, acquired when juvenile, were raised in semi captivity since 2002 and started being exploited as prey by D. rotundus in the same year. Desmodus rotundus attacks exterminated ca. 100 adult birds by the beginning of 2003 . A new lot of birds (ca. 100 subadults) were introduced in July 2005, which started being attacked in August, resulting in an estimated loss of $1 / 3$ of all birds in the same year. From 2006 on, the remaining birds (approximately 25\% of the total introduced since 2005) started being managed, sleeping in a henhouse built for protection and provided with light all night long, which resulted in a decrease in the attack rate, but did not completely prevent attacks. A new lot was introduced in 2007, with part of the birds resting during the night inside the henhouse and part over branches. A new mortality estimated in $2 / 3$ of all new birds occurred within less than six months. In this locality, the capture and euthanasia of $D$. rotundus was periodically carried out (33 nights from 2004 to 2009, with the capture of 40 specimens) resulting only in a temporary reduction of the attack rate. Vampire bat attacks were also observed on this island on two adult goats, a Rottweiller dog, a donkey, and one human, probably as an outcome of the prey reduction or of the management started in 2006 . The presence of a high population density of hematophagous bats before 2002 on this island would be easily detected by attacks on other domestic animals before the introduction of the helmeted guinea fowl, such as peacocks, turkeys, dogs or even humans. The hypothesis that hematophagous bats move from the continent to the island may be still sustained by the lack of captures during some sampling periods (2005 and 2008) and a high capture rate during other periods (2004, 2005 and 2007). Another interesting fact was the capture of a specimen of $D$. youngi on the $31^{\text {st }}$ sampling night, which coincided with the mortality, reported a few weeks before, of part of the peacocks that slept $180 \mathrm{~m}$ away from the nets, on branches over $10 \mathrm{~m}$ high (see Costa et al. (2008) for other cases in this region). Such a fact suggests that both $D$. youngi and D. rotundus may have arrived on the island recently. The species had not been observed in the locality until then and there was no previous record of death or attack on this bird species in this site.

In Ilha da Marambaia, vampire bat attacks on domestic animals introduced were reported during the island occupation phase with farming and cattle raising activities (in the 
1940s and 1960s). Currently the number of herbivores is scant and the activities on the island are restricted almost exclusively to fishery and military training. Inhabitants reported the continuous death of domestic birds by attacks of hematophagous bats in previous years, before the surveying accomplished in the present study. Between October 2006 and December 2007, seven inhabitants were attacked by $D$. rotundus in at least two different localities. We captured a couple of $D$. rotundus at 8:00 PM while entering a house on this island, where the attack on one inhabitant for several nights was reported. More than 30 vampire bats were netted and sacrificed between the 2006 and 2009 samplings on this island.

Desmodus rotundus is a gregarious species, which forms groups composed of a dominant male, a subordinate male and several females, and it is possible that all or part of them disperse and forage together (Forment et al., 1971; Wilkinson, 1986, 1988, 1990). It is more likely that bats captured in the present study moved from the continent to one or more islands, where they settled until the reduction of abundance or extinction of prey, and then moved to another island or even returned to the continent. At least on three other islands, which have not been sampled yet, attacks on domestic animals (dogs, chickens and peacocks) have already been reported.

The presence of $D$. rotundus outside the rural area is considered a consequence of deforestation (e.g. Schneider et al., 1996, 2001). Such a fact does not seem to be coherent at least in the region studied, since the southeastern coast of Rio de Janeiro state has presently the largest forested area of the whole state and shows the best conservation status (Rocha et al. 2003). Besides, deforestation is currently rare, and in this region livestock farming activities are very scant (Ururahy et al., 1983; CIDE, 1996).

Due to the importance of $D$. rotundus in the transmission of the rabies virus (Constantine, 1988; Brass, 1994), measures to control this bat are strongly requested. In order to minimise the frequency of attacks it is important to avoid the introduction of new domestic animals onto the islands and the existence of this bat species in those sites must be informed if attacks occur. Measures to avoid attacks on human beings must be taken, such as guiding inhabitants to install a nylon or wire net in every opening of their houses. Settling a regular control of the species by a team properly trained for this procedure, and to start a local information network to report attacks may be useful. Due to the flow of the rabies virus among the specimens of $D$. rotundus (Langoni et al., 2008), a sanitary and epidemiological monitoring of the whole southern coast of Rio de Janeiro state is also important.

Acknowledgements - Club Méd, Secretaria de Saúde de Angra dos Reis, PESAGRO-RIO, Fazenda da Gipóia-SOGIM, Fazenda Portobello, Centro de Adestramento da Ilha da Marambaia and UERJ for logistic support. We also thank the field assistance of J. Almeida, L. Cristina, M.C. Enrici, A.F.P.D. Fernandes, D.S. França, L.C. Gomes, T. Jordão-Nogueira, E.C. Lourenço, J.L. Luz, A.G. Motta and P. Nogueira. This study was developed under a special sampling permit from IBAMA-DF (processes \# 1755/89, 4156/95-46 and SISBIO \# 10361-0). C.E.L. Esbérard is grateful for his Research Productivity Fellowship from CNPq (process \# 301061/2007-6) and from FAPERJ (process \# E-26/102.799/2008).

\section{References}

ACHA, PN. and MALAGA-ALBA, A., 1988. Economic losses due to Desmodus rotundus. In GREENHALL, AM. and SCHMIDT, U. (Eds). Natural History of Vampire Bats. Florida: Boca Raton, CRC Press. p. 207-214.

ALHO, CJR., SCHNEIDER, M. and VASCONCELOS, LA., 2002. Degree of threat to the biological diversity in the Ilha Grande State Park (RJ) and guidelines for conservation. Revista Brasileira de Biologia = Brazilian Journal of Biology, vol. 62, no. 3, p. 375-385.

ALMANSA, JC. and GARCIA, RC., 1980. Incidencia del murciélago hematófago Desmodus rotundus sobre los indígenas Yanomami de Venezuela. Doñana Acta Vertebrata, vol. 7, p. 113-117.

ARAUJO, D. and OLIVEIRA, R., 1988. Reserva Biológica Estadual da Praia Sul (Ilha Grande, Estado do Rio de Janeiro): Lista preliminar de flora. Acta Botânica Brasilica, vol. 1, p. 83-94.

BAER, GM. 1991. The natural history of rabies. 2nd ed. Boca Raton, Florida: CRC Press. 660 p.

BRASS, DA., 1994. Rabies in bats, natural history and public health implications. Ridgefield, Connecticut: ED Livia. 335 p.

BREDT, A., ARAÚJO, FAA., CAETANO-JÚNIOR, J., RODRIGUES, MGR., YOSHIZAWA, M., SILVA, MMS., HARMANI, NMS., MASSUNAGA, PNT., BÜRER, SP., PORTO, VAR. and UIEDA, W., 1996. Morcegos em áreas urbanas e rurais: manual de manejo e controle. Brasília: Fundação Nacional de Saúde. 117 p.

BREDT, A. and UIEDA, W., 1996. Bats from urban and rural environments of the Distrito Federal, Mid-western Brazil. Chiroptera Neotropica, vol. 2, no. 2, p. 54-57.

CARRANZA, J. and DEL-CAMPO, R., 1980. Incidências del murciélago hematófago Desmodus rotundus sobre los indígenas Yanomami del Alto Orinoco (Venezuela). Doñana Acta Vertebrata, vol. 7, no. 1, p. 113-117.

COSTA, LM., OLIVEIRA, DM., FERNANDES, AFPD. and ESBÉRARD, CEL., 2008. Ocorrência de Diaemus youngi (Jentink 1893), Chiroptera, no estado do Rio de Janeiro. Biota Neotropica, vol. 8, no. 1, p. 217-220.

Centro de Informações e Dados do Rio de Janeiro - CIDE . 1996. Anuário estatístico do Estado do Rio de Janeiro. Rio de Janeiro: FIDERJ-FAPERJ. $351 \mathrm{p}$.

CONSTANTINE, DG. 1988. Transmission of pathogenic microorganisms by vampire bats. In GREENHALL, AM. and SCHMIDT, U. (Eds.). Natural history of vampire bats. Boca Raton, Florida: CRC Press. p. 167-89.

CRESPO, JA., VANELLA, JM., BLOOD, BD. and DE CARLO, JM., 1961. Observaciones ecológicas del vampiro Desmodus rotundus en el norte de Córdoba. Revista del Museum Argentino Ciências Naturales Bernardino Rivadavia, vol. 4, no. 6, p. 131-160.

DELPIETRO, HA., MARCHEVSKY, N. and SIMONETTI, E., 1992. Relative population densities and predation of the common vampire bat (Desmodus rotundus) in natural and cattle-raising 
areas in north-east Argentina. Preventive Veterinary Medicine, vol. 14 , no. $1 / 2$, p. $13-20$.

ESBÉRARD, CEL. 2003. Diversidade de morcegos em uma área de Mata Atlântica regenerada no sudeste do Brasil (Mammalia: Chiroptera). Revista Brasileira de Zoociências, vol. 5, no. 2, p.189-204.

-, 2009. Capture sequence and relative abundance of bats during surveys. Revista Brasileira de Zoologia, vol. 26, no.1, p. 103-108.

ESBÉRARD, CEL. and BERGALLO, HG., 2008. Influência do esforço amostral na riqueza de espécies de morcegos no sudeste do Brasil. Revista Brasileira de Zoologia, vol. 25, no. 1, p. 67-73.

ESBÉRARD, CEL., CHAGAS, AS., LUZ, EM., CARNEIRO, RA. and MARTINS LF., 1998. Considerações sobre o morcego hematófago (Desmodus rotundus) na cidade do Rio de Janeiro, RJ, Brasil. Revista Brasileira de Medicina Veterinária, vol. 19, no. 5 , p. 209-215.

ESBÉRARD, CEL., CIFALI, AP. and THEBBAS F., 2001. Ação de morcegos hematófagos no Município do Rio de Janeiro. Revista Brasileira de Medicina Veterinária, vol. 23, no. 5, p. 219-220.

ESBÉRARD, CEL., JORDÃO-NOGUEIRA, T., LUZ, JL., MELO, GGS., MANGOLIM, R., JUCÁ, N., RAÍCES, DSL., ENRICI, MC. and BERGALLO, HG., 2006. Morcegos da Ilha Grande, Angra dos Reis, RJ, Sudeste do Brasil. Revista Brasileira de Zoociência, vol. 8, no. 2, p. 147-153.

FARIA, D., SOARES-SANTOS, BS. and SAMPAIO, S. 2006. Bats from the Atlantic forest of Southern Bahia, Brazil. Biota Neotropica, vol. 6, no. 2, p. 1-13. http://dx.doi.org/10.1590/ S1676-06032006000200022

FERRAZ, C., ACHKAR, SM. and KOTAIT, I., 2007. First report of rabies in vampire bats (Desmodus rotundus) in an urban area, Ubatuba, São Paulo state, Brazil. Revista Instituto Medicina Tropical de São Paulo, vol. 49, no. 6, p. 389-390. http://dx.doi. org/10.1590/S0036-46652007000600010

FIDALGO, ECC., UZEDA, MC., BERGALLO, HG. and COSTA, TCC., 2007. Remanescentes da Mata Atlântica no Estado do Rio de Janeiro: distribuição dos fragmentos e possibilidades de conexão. Anais XIII Simpósio Brasileiro Sensoriamento Remoto, 2007. Rio de Janeiro. p. 3885-3892.

FORMENT, WL., SCHMIDT, U. and GREENHALL, AM., 1971. Movement and population studies of the vampire bat (Desmodus rotundus) in Mexico. Journal of Mammalogy, vol. 52, p. 227-228. PMid:5545561. http://dx.doi.org/10.2307/1378457

GARDNER, AL., 1977. Feeding habits. In BAKER, RJ., JONES, JK. and CARTER, DC. (Eds.). Biology of bats of the New World family Phyllostomatidae, Part II. The Museum Texas Tech University, Special Publications. p. 293-350.

GOMES, MN. and UIEDA, W., 2004. Abrigos diurnos, composição de colônias, dimorfismo sexual e reprodução do morcego hematófago Desmodus rotundus (E. Geoffroy) (Chiroptera, Phyllostomidae) no Estado de São Paulo, Brasil. Revista Brasileira de Zoologia, vol. 21 , no. 3 , p. $629-638$.

GONÇALVES, MA., SÁ-NETO, RJ. and BRAZIL, TK., 2002. Outbreak of aggressions and transmission of rabies in human beings by vampire bats in northeastern Brazil. Revista Sociedade Brasileira de Medicina Tropical, vol. 35, no. 3, p. 461-464. PMid:12621664

GREENHALL, AM. and SCHMIDT, U., 1988. Natural history of vampire bats. Florida: Bocca Raton, CRC Press. 247 p.
JONES, JC. 1976. Economics and conservation., The Museum Texas Tech University, Special Publications. p. 133-145. vol. 10.

LANGONI, H., SOUZA, LC., ZETN, CB., SILVA, TCC., HOFFMAN, JL. and SILVA, RC., 2008. Serological survey for rabies in serum samples from vampire bats (Desmodus rotundus) in Botucatu region, SP, Brazil. Journal of Venomous Animals and Toxins including Tropical Diseases, vol. 14, no. 4, p. 651-659. http://dx.doi.org/10.1590/S1678-91992008000400008

LINHART, SB., 1975. The biology and control of vampire bats. In BAER, GM. (Ed.). The natural history of rabies. New York: Academic Press. p. 221-241. vol. 2.

MÁLAGA-ALBA, A., 1954. Vampire bat as a carrier of rabies. American Journal of Public Health, vol. 44, p. 909-918. PMid:13171471. PMCid:1620809. http://dx.doi.org/10.2105/ AJPH.44.7.909

MACIEL, NC., ARAUJO, DSD. and MAGNANINI, A., 1984. Reserva Estadual da Praia do Sul (Ilha Grande, Angra dos Reis, RJ): contribuição para conhecimento da fauna e flora. Boletim da Fundação para Conservação da Natureza, vol. 19, p. 126-148.

MAYEN, F., 2003. Haematophagous bats in Brazil, their role in rabies transmission, impact on public health, livestock industry and alternatives to an indiscriminate reduction of bat population. Journal of Veterinary Medical, vol. 50, p. 469-72. PMid:14720182. http://dx.doi.org/10.1046/j.1439-0450.2003.00713.x

MEDINA, A., HARVEY, CA., MERLO, DS., VÍLCHEZ, S. and HERNÁNDEZ, B. 2007. Bat diversity and movement in an agricultural landscape in Matiguás, Nicaragua. Biotropica, vol. 39 , no. 1, p.120-128.

McCARTHY, TH., 1989. Human Depredation by Vampire Bats (Desmodus rotundus) Following a Hog Cholera Campaign. American Journal of Tropical Medicine and Hygiene, vol. 40, no. 3, p. 320-322. PMid:2929856

McNAB, BK., 1973. Energetics and the distribution of vampires. Journal of Mammalogy, vol. 54, p. 131 - 44. http://dx.doi. org/10.2307/1378876

NOWAK, RM., 1995. Walker's mammals of the world. 4nd ed. Baltimore: John Hopkins University. 1629 p.

PEDRO, W. and TADDEI, VA., 1997. Taxonomic assemblage of bats from Panga Reserve, Southeastern Brazil: abundance patterns and trophic relations in the Phyllostomidae (Chiroptera). Boletim do Museu de Biologia Mello Leitão (Nova Série), vol. 6, no. 1, p. 3-21.

PERACCHI, AL. and ALBUQUERQUE, ST. 1993. Quirópteros do Município de Linhares, Estado do Espirito Santo, Brasil (Mammalia: Chiroptera). Revista Brasileira de Biologia $=$ Brazilian Journal of Biology, vol. 53, no. 4, p. 575-581.

PEREIRA, LG., TORRES, SEM., DA SILVA, HS. and GEISE, L., 2001. Non-volant mammals of Ilha Grande and adjacent areas in Southern Rio de Janeiro State, Brazil. Boletim do Museu Nacional, vol. 459, p. 1-15.

PORTFORS, CV., FENTON, MB., AGUIAR, LMS., BAUMGARTEN, JE., VONHOF, MJ., BOUCHARD, S., FARIA, DM., PEDRO, WA., RAUNTEBACH, NIL. and ZORTÉA, M., 2000. Bats from Fazenda Intervales, Southeastern Brazil - species account and comparison between different sampling methods. Revista brasileira de Zoologia, vol. 17, no. 2, p. 533-538.

ROCHA, CFD., BERGALLO, HG., ALVES, MAS. and van SLUYS, M., 2003. A biodiversidade nos grandes remanescentes 
florestais do Estado do Rio de Janeiro e nas Restingas da Mata Atlântica. São Carlos: RiMa.

SCHNEIDER, MC., ARON, J., SANTOS-BURGOA, C., UIEDA, W., RUIZ-VELAZCO, S., 2001. Common vampire bat attacks on humans in a village of the Amazon region of Brazil. Cadernos de Saúde Pública, vol. 17, no. 6, p. 1531-1536. PMid:11784915

SCHNEIDER, MC., SANTOS-BORGOA, C., ARON, J., MUÑOZ, B., RUIZ-VELASCO, S. and UIEDA, W., 1996. Potential force of infection of human rabies transmitted by vampire bats in the Amazonian region of Brazil. American Journal of Tropical Medicine and Hygiene, vol. 5, p. 680-684.

TADDEI, VA. and PEDRO, W. 1996. Morcegos (Chiroptera: Mammalia) do Vale do Ribeira, Estado de São Paulo: diversidade de espécies. In SANTOS, JE. (Ed.). Anais do VIII Seminário Regional de Ecologia. São Carlos: Universidade Federal de São Carlos. p 911-919.

TEIXEIRA, SC. and PERACCHI, AL. 1996. Morcegos do Parque Estadual da Serra da Tiririca, Rio de Janeiro, Brasil (Mammalia, Chiroptera). Revista Brasileira de Zoologia, vol. 13, no. 1, p. 61-66.

TORRES, FD., VALENCIA, C. and ANDRADE FILHO, GV., 2005. First Record of Desmodus rotundus in urban area from the city of Olinda, Pernambuco, northeastern Brazil: A case report. Revista Instituto Medicina Tropical de São Paulo, vol. 47, no. 2, p. 107 - 108. PMid:15880224

TURNER, DC., 1975. The Vampire Bat. A field study in behavior and ecology. Baltimore: John Hopkins Press. 145 p.

URURAHY, JCC., COLLARES, JER., SANTOS, MM. and BARRETO, RAA., 1983. Folhas SF.23/24 Rio de Janeiro/Vitória, geologia, geomorfologia, pedologia, vegetação e uso potencial da terra. Rio de Janeiro: Instituto Brasileiro de Geografia e Estatística. Projeto RADAMBRASIL, As regiões fitoecológicas, sua natureza e seus recursos econômicos. Estudo fitogeográfico.

WIMSATT, WA., 1969. Transient behavior, nocturnal activity patterns, and feeding efficiency of vampire bats (Desmodus rotundus) under natural conditions. Journal of Mammalogy, vol. 50, p. 233-44. http://dx.doi.org/10.2307/1378339

WILKINSON, GS., 1986. Social grooming in the common vampire bat, Desmodus rotundus. Animal Behavior, vol. 34, p. 1880-1886. http://dx.doi.org/10.1016/S0003-3472(86)80274-3

WILKINSON, GS., 1988. Social organization and behavior, In GREENHALL, AM. and SCHMIDT, U. (Eds.). Natural history of vampire bats. Florida: CRC Press. p. 85-97.

WILKINSON, G., 1990. Food sharing in vampire bats. Scientific American, vol. 262, no. 2, p. 64-70. http://dx.doi.org/10.1038/ scientificamerican0290-76 